\title{
FRAMING NEWS ABOUT INDONESIAN CAPITAL CITY TRANSLOCATION BY ONLINE MEDIA OKEZONE.COM AND VIVA.CO.ID
}

\author{
Alifia Pradyanti ${ }^{(1)}$, Antar Venus $^{(2)}$, Vina Mahdalena ${ }^{(3)}$ \\ Program Studi Ilmu Komunikasi, FISIP Universitas Pembangunan Nasional "Veteran" Jakarta \\ Jalan R.S Fatmawati, Pangkalan Jati, Cilandak, Cinere, Kota Jakarta Selatan 16514
}

Email: (1) alifiapradyant@upnvi.ac.id, (2) venusantar@yahoo.com, (3) Vinamahdalena@upnvi.ac.id

\begin{abstract}
Abstrak
This study discusses how online media Okezone.com and Viva.co.id frame the news of the Moving of the Indonesian Capital. The research approach used is descriptive qualitative using framing theory. The method used is the Zhongdan Pan and Gerald M. Kosick Model. The model analyzes with four structures namely Syntax (title, lead, background information, source and closing quotes) Scripts (completeness of $5 \mathrm{~W}+1 \mathrm{H}$ news items), Thematic (paragraph propositions between sentences) and Rhetorical (words, idioms, pictures/photographs). This study uses document study data collection techniques originating from uploads of both online media in July-September 2019 related to the Moving of the Indonesian Capital so that six news were collected that were examined as a data analysis unit in this study. The findings obtained from the syntactic structure of the two media use the opposite title, whereby the background information used by Okezone.com is more to the government while Viva.co.id is more to the public. In the structure of the script Okezone.com fulfills the news element, but the resource persons chosen are only one point of view, while Viva.co.id has not fulfilled the news element in the third news. In the thematic structure the two media differ in highlighting their contents even with the same theme. For the rhetorical element, the use of images in both media is sufficient to explain the contents of the news. It is hoped that further research can emphasize media ideology in framing an event. In addition, the media can also display more than one resource so that it can be seen from various points of view. The community itself is expected to dig deeper information by not only from one media.
\end{abstract}

Keywords: Online media, framing, moving the capital

\section{PENDAHULUAN}

Indonesia merupakan salah satu negara yang memiliki keberagaman. Keberagaman di Indonesia berasal dari daerah-daerah yang ada. Adanya berbagai budaya, bahasa, sumber daya alam membuat Indonesia menjadi unik dan beragam. Jakarta merupakan Ibu kota Indonesia yang memiliki ciri khas sebuah bangunan di Jakarta pusat yang biasa disebut Monumen Nasional atau Monas. Jakarta sendiri dipimpin oleh seorang gubernur. Hingga saat ini, Jakarta sudah berganti gubernur sebanyak 17 kali. Anies Rasyid Baswedan merupakan pemimpin Jakarta di 
periode ini. Tidak hanya berganti gubernur saja, Ibu kota Indonesia pun sempat berlokasi di Jogjakarta dan Bukittinggi. Setelah 70 tahun lamanya, kini terdapat isu menarik mengenai pemindahan Ibu kota Indonesia.

Adanya isu menarik ini tentunya terdapat berbagai pendapat dari berbagai pihak. Pro dan kontra tentu akan bermunculan seiring dengan adanya isu yang sedang hangat dibahas ini. Dengan perkembangan teknologi, isu pemindahan Ibu kota pun semakin meluas dengan cepat. Masyarakat kerap kali menggunakan media massa untuk memperoleh informasi. Dengan perkembangan teknologi, terciptalah internet sebagai salah satu cara mengakses "news media" atau media online. Survei intensia yang ditulisan oleh media online Tempo.co di tahun 2019 menunjukkan 34,2\% netizen setuju dengan adanya pemindahan Ibu kota Indonesia. Sedangkan sebanyak 16.5\% netizen tidak setuju dengan pemindahan Ibu kota dengan alasan kurang paham terhadap konsep, maksud, maupun tujuan dari pemindahan Ibu kota tersebut. Dalam jurnalisme, salah satu hal yang paling mencolok adalah redupnya bisnis media cetak di semua negara. Khalayak lebih memilih informasi yang disediakan gratis oleh internet (Wendratama, 2017).

Media massa yang paling sering digunakan saat ini adalah televisi, radio, dan internet untuk mencari informasi, edukasi, maupun rekreasi. Menurut Effendi (2003), media massa digunakan dalam komunikasi apabila komunikasi berjumlah banyak dan bertempat tinggal jauh. Dalam memberitakan suatu topik atau isu yang diangkat, media mengemas serta membingkai peristiwa dari berbagai aspek. Aspek yang diperhatikan media dalam mengemas dan membingkai berita adalah fakta yang didapatkan saat peliputan serta bahasa dan kata yang baik dan benar dalam menuliskan informasi yang diperoleh ke dalam portal media online tersebut. Kepemilikan media yang berlatar belakang politik pun kini menjadi semakin menarik; bagaimana media tersebut mempertahankan fakta pemberitaan maupun ideologi media yang mereka miliki-pembingkaian yang dilakukan oleh media pada satu topik yang sama-khususnya pada topik pemindahan Ibu kota Indonesia ini.

Adapun media online yang akan diteliti adalah Okezone.com dan Viva.co.id karena media online merupakan media yang paling mudah diakses kapan pun dan dimana pun. Selain itu, kepemilikan dari kedua media online tersebut juga berbeda dan berkaitan dengan isu yang akan diteliti. Okezone.com merupakan milik MNC group yang dikelola oleh Hary Tanoesoedibjo dari partai Perindo. Okezone.com sendiri memberitakan isu pemindahan Ibu kota dengan mendukung hal tersebut. Pemberitaannya mengarah kepada hal-hal positif yang akan berpengaruh kepada Indonesia ke depannya. Namun, jika diperhatikan, Perindo sendiri merupakan salah satu partai yang menjadi koalisi kemenangan Jokowi pada pemilihan preside 2019-2024 ini.

Sedangkan Viva.co.id merupakan media online di bawah naungan PT. Viva Media Baru Tbk yang merupakan milik Bakrie group yang dipimpin oleh Aburizal Bakrie. Aburizal Bakrie sendiri berasal dari partai Golkar. Meskipun Golkar merupakan salah satu partai koalisi Jokowi pada pemilihan presiden 2019-2024, Viva.co.id lebih banyak menuliskan pemberitaan kontra terhadap isu pemindahan Ibu kota Indonesia. Pemberitaan tersebut melalui ketidaksetujuan seorang politisi dari fraksi Gerindra yaitu Fadli Zon. Apabila diperhatikan, Fadli Zon merupakan wakil ketua Gerindra. Ketua Gerindra, yakni Prabowo Subianto, yang dikenal sebagai pesaing Jokowi pada pemilihan presiden tahun ini. Selain itu, Fadli Zon juga menduduki kursi wakil DPR I dan ketua DPR saat itu adalah Setya Novanto yang berasal dari partai Golkar.

\section{Studi Pustaka dan Kajian Teori}

Desiana (2016) menyampaikan bahwa penelitiannya terkait penyerangan Isis di Paris ini menunjukkan, pembingkaian berita pada ketiga media cetak ini mengambil dari sudut pandang yang berbeda. Maka dari itu 
hasil pemikiran pembaca antara ketiga media tersebut akan berbeda karena pembingkaian media nya pun berbeda sudut pandang dan pengemasan berita. Pembingkaian berita bisa menjadi hasil pemikiran positif atau negatif.

Sedangkan Losianti, Maya (2015) mengatakan hasil penelitiannya terkait mundurnya Surya Paloh dari partai Golkar merupakan diskusi mengenai pembingkaian berita yang dilakukan oleh media online Viva.co.id. Dari hasil analisis pembingkaian tersebut terlihat bahwa media online Viva.co.id masih menunjukkan usaha media untuk melakukan pendekatan pada objektifitas pemberitaan. Hal ini menunjukkan bahwa netralitas dan objektifitas media dipengaruhi oleh kepemilikan media.

Sedangkan pada teori penelitian ini menggunakan teori framing yang dikemukakan oleh Zhongdan Pan dan Gerald M. Kosicki dalam empat struktur pembingkaian. Pengambilan teori ini karena dapat diteliti dengan menyeluruh dari struktur sintaksis yaitu bagaimana cara wartawan dalam menyusun fakta, struktur skrip yaotu bagaimana cara wartawan mengisahkan fakta, struktur tematik yaitu bagaimana cara wartawan menuliskan fakta serta struktur retoris yaitu bagaimana wartawan menekankan fakta. Sehingga terlihat bagaiman dua media yang dipilih membingkai sebuah berita terkait pemindahan Ibu kota Indonesia.

\section{METODE}

Metode penelitian yang digunakan adalah kualitatif deskriptif. Pada penelitian ini akan mendeskripsikan bagaimana pembingkaian berita yang dilakukan oleh masing-masing media online yang telah ditentukan. Pengumpulan data terbagi menjadi dua yaitu primer dan sekunder. Pada dasarnya data sekunder merupakan teknik pengumpulan data untuk menyempurnakan informasi yang belum didapatkan pada data primer, sehingga data menjadi lebih lengkap untuk dilanjutkan pada penelitian. Namun, pada penelitian ini hanya menggunakan pengumpulan data primer saja. Pengumpulan data primer dapat dilakukan dengan studi dokumen. Menurut Bungin (dalam Sugiyono, 2017) metode dokumenter adalah salah satu metode pengumpulan data yang digunakan dalam metodologi penelitian sosial untuk menelusuri data historis.

Studi dokumen yang dilakukan dalam penelitian ini adalah mengumpulkan unggahan berita pada media online Okezone.com dan media online Viva.co.id pada periode Juli, Agustus dan September mengenai isu pemindahan Ibu kota Indonesia. Pada proses pengumpulan data pada kedua media online tersebut, terkumpul 50 berita dari media online Okezone.com dan 37 berita dari media online Viva.co.id. Berita yang sudah terkumpul kemudian dirangkum dalam 3 tema besar yaitu transportasi, pegawai negeri sipil dan masyarakat. Ketiga tema tersebut diteliti menggunakan teori framing Zhongdan Pan dan M. Kosicki. Untuk melihat pembingkaian berita pemindahan Ibu kota Indonesia oleh kedua media online tersebut.

Model ini berasumsi bahwa setiap berita dibingkai, dengan fungsi sebagai pusat organisasi ide. Bingkai tersebut dihubungkan dengan elemen sumber, latar belakang informasi, pemakaian kata atau kalimat tertentu untuk membuat teks secara keseluruhan. Pembingkaian ini berhubungan dengan makna, bagaimana seseorangmemaknai peristiwa yang diberitakan dalam teks suatu media.

\section{HASIL DAN PEMBAHASAN}

Pada teori framing model ini berasumsi bahwa setiap berita dibingkai, dengan fungsi sebagai pusat organisasi ide. Bingkai tersebut dihubungkan dengan elemen sumber, latar belakang informasi, pemakaian kata atau 
kalimat tertentu untuk membuat teks secara keseluruhan. Pembingkaian ini berhubungan dengan makna, bagaimana seseorangmemaknai peristiwa yang diberitakan dalam teks suatu media.

Tabel 1 Struktur Model Pan dan Kosicki

\begin{tabular}{|c|c|c|}
\hline Struktur & Perangkat Framing & Unit yang Diamati \\
\hline $\begin{array}{l}\text { Sintaksis } \\
\text { Cara wartawan menyusun } \\
\text { fakta }\end{array}$ & Skema berita & $\begin{array}{l}\text { Headline, lead, latar informasi, kutipan, } \\
\text { sumber, pernyataan penutup. }\end{array}$ \\
\hline $\begin{array}{l}\text { Skrip } \\
\text { Cara wartawan mengisahkan } \\
\text { fakta }\end{array}$ & Kelengkapan berita & $5 \mathrm{~W}+1 \mathrm{H}$ \\
\hline $\begin{array}{l}\text { Tematik } \\
\text { Cara wartawan menulis } \\
\text { fakta }\end{array}$ & $\begin{array}{l}\text { 1. Detail } \\
\text { 2. Maksud kalimat, hubungan } \\
\text { 3. Nominalisasi antarkalimat } \\
\text { 4. Koherensi (Bentuk kalimat, kata } \\
\text { ganti) }\end{array}$ & Paragraf, proposisi \\
\hline $\begin{array}{l}\text { Retoris } \\
\text { Cara wartawan menekankan } \\
\text { fakta }\end{array}$ & $\begin{array}{l}\text { 1. Leksikon } \\
\text { 2. Grafis } \\
\text { 3. Metafor (Pengandaian) }\end{array}$ & $\begin{array}{l}\text { Kata, idiom, gambar atau foto dan } \\
\text { grafik. }\end{array}$ \\
\hline
\end{tabular}

Sumber: Nurhadi (2015)

Berdasarkan data yang dikumpulkan, terdapat 50 berita dari media online Okezone.com dan 37 berita dari media online Viva.co.id mengenai pemindahan Ibu kota Indonesia. Pengumpulan data tersebut berdasarkan berita yang diunggah kedua media online pada periode Juli, Agustus, dan September 2019. Setelah terkumpul data yang ada, terdapat 3 tema besar yang akan diteliti. Ketiga tema tersebut merupakan fokus penelitian ini.

Tabel 2 Unit Analisis Data

\begin{tabular}{|c|c|c|c|c|}
\hline Tanggal & Okezone.com & \multicolumn{2}{|l|}{ Tanggal } & Viva.co.id \\
\hline \multicolumn{5}{|c|}{ Tanggapan Masyarakat Kalimantan } \\
\hline $\begin{array}{l}17 \text { Agustus } 2019 \text { 05:25 } \\
\text { WIB }\end{array}$ & $\begin{array}{ll}\text { Pemindahan Ibu } & \text { Kota } \\
\text { Negara Disambut } & \text { Baik } \\
\text { Warga Kalimantan } & \end{array}$ & $\begin{array}{l}7 \quad \text { September } \\
\text { 18:50 WIB }\end{array}$ & 2019 & $\begin{array}{l}\text { Kecemasan Warga Dayak } \\
\text { Paser Saat Ibu Kota Pindah ke } \\
\text { Kalimantan Timur }\end{array}$ \\
\hline \multicolumn{5}{|c|}{ Nasib dan Tanggapan Pegawai Negeri Sipil (PNS) Jakarta } \\
\hline $\begin{array}{l}03 \text { September } 2019 \\
\text { 12:30 WIB }\end{array}$ & $\begin{array}{l}\text { BKN Susun Strategi } \\
\text { Pindahkan PNS ke Ibu Kota } \\
\text { Baru }\end{array}$ & $\begin{array}{l}28 \text { Agustus } \\
12: 22 \text { WIB }\end{array}$ & 2019 & $\begin{array}{l}\text { PNS Cemas Pindah ke Ibu } \\
\text { Kota Baru, Khawatir Tak } \\
\text { Selengkap Jakarta }\end{array}$ \\
\hline \multicolumn{5}{|l|}{ TRANSPORTASI } \\
\hline $\begin{array}{l}13 \text { September } 2019 \\
\text { 15:19 WIB }\end{array}$ & $\begin{array}{l}\text { Ibu Kota Baru Akan Miliki } \\
\text { Kereta Berbasis Listrik }\end{array}$ & $\begin{array}{l}26 \quad \text { Agustus } \\
\text { 10:14 WIB }\end{array}$ & 2019 & $\begin{array}{l}\text { Ibu Kota Siap Pindah, Sistem } \\
\text { Transportasinya Apa Kabar? }\end{array}$ \\
\hline
\end{tabular}

Sumber: Okezone.com dan Viva.co.id, 2019 dan diolah peneliti

Dari hasil unit analisis data, berikut ini merupakan hasil analisis pembingkaian berita pemindahan Ibu kota pada beberapa tema. 


\section{Tanggapan Masyarakat Kalimantan}

\section{Hasil Analisis Berita 1}

Hasil analisis pada berita pertama yaitu perbedaan judul pada kedua media online tersebut. Judul yang dipilih kedua media online menekankan pada pendapat masyarakat terhadap pindahnya Ibu kota Indonesia ke Kalimantan Timur. Media online Okezone.com menggunakan judul Pemindahan Ibu Kota Negara Disambut Baik Warga Kalimantan, yang artinya warga Kalimantan mendukung pindahnya Ibu kota ke daerah mereka (mengarah kepada hasil yang positif terhadap keputusan pemerintah), sedangkan media online Viva.co.id menggunakan judul Kecemasan Warga Dayak Paser Saat Ibu Kota Pindah ke Kalimantan Timur. Terdapat makna warga Dayak Paser merasa cemas jika Ibu kota negara akan dipindahkan ke daerah mereka sehingga judul kedua media online itu sendiri sudah bisa menggiring opini atau pemikiran pembaca.

Jika dilihat dari latar informasi, informasi yang diberikan Viva.co.id lebih detail dan rinci dibandingkan dengan Okezone.com. Viva.co.id menjelaskan secara rinci mengapa warga Dayak Paser tidak setuju atau khawatir jika Ibu kota akan dipindahkan ke Kalimantan Timur.

Hal tersebut berkesinambungan dengan kutipan narasumber yang digunakan kedua media online tersebut. Viva.co.id menghadirkan dua narasumber dari dua sudut pandang (cover both sides). Dari judul yang digunakan keduanya sama-sama mengambil sudut pandang dari masyarakat. Namun, Viva.co.id tetap menghadirkan kutipan dari pemerintah yang menjawab kekhawatiran dari masyarakat Dayak Paser itu sendiri, sedangkan Okezone.com hanya menghadirkan narasumber yang mendukung pemindahan Ibu kota yaitu dari segi pemerintah Kalimantan saja.

Terdapat pula perbedaan pernyataan penulis atau wartawan dalam berita. Okezone.com menuliskan opini untuk pemerintah terhadap lahan yang akan dibangun pemerintah. Namun, terdapat opini tentang pemerintah yang akan mengikutsertakan warga Kalimantan Timur dalam pembangunan Ibu kota baru sehingga akan tercipta keselarasan tujuan bersama, sedangkan opini yang dituliskan oleh penulis atau wartawan Viva.co.id lebih detail, dimulai dari fokus pada lahan dan nasib warga Dayak Paser serta janji pemerintah kepada masyarakat Dayak Paser jika Ibu kota benar-benar akan dipindahkan ke daerah mereka.

Untuk struktur skrip, kedua media online tersebut sudah memenuhi unsur berita, yaitu $5 \mathrm{~W}+1 \mathrm{H}$ sehingga informasi yang disampaikan jelas sumbernya. Tidak hanya pada struktur skrip saja, pada struktur tematik pun kedua media online ini memiliki proposisi paragraf yang berkesinambungan sehingga penulisan alur antar paragraf jelas menjadi satu kesatuan informasi. Hal demikian didukung dengan kutipan narasumber yang memberikan informasi terkait pembahasan pada paragraf tersebut.

Penggunaan gambar oleh kedua media online tersebut berbeda. Viva.co.id dianggap sesuai dalam pemilihan gambar dengan judul, berbeda dengan Okezone.com yang dianggap tidak sesuai dalam meselaraskan antara judul berita dengan gambar yang digunakan. Hal tersebut dilihat dari gambar Viva.co.id yang menggunakan foto dua orang warga Dayak Paser yang terlihat bingung atau khawatir sedangkan Okezone.com hanya menggunakan gambar sebuah peta yang terlihat kusam karena pemilihan warnanya. 


\section{Nasib dan Tanggapan Pegawai Negeri Sipil di Jakarta}

\section{Hasil Analisis Berita 2}

Hasil analisis pada berita kedua yaitu perbedaan judul pada kedua media online tersebut. Kedua media samasama mengusung tema tentang bagaimana nasib PNS di Ibu kota negara yang baru. Namun, dari segi judul terdapat perbedaan yang cukup kontras. Okezone.com, dalam judulnya, lebih mengarah kepada strategi yang dilakukan oleh BKN yaitu lebih pada sudut pandang pemerintah sedangkan Viva.co.id mengarah kepada alasan PNS di Jakarta khawatir jika mereka akan dipindahkan dan lebih mengarah kepada perasaan masyarakat sehingga dari judul kedua media online, tampak perbedaan ke arah pembahasan meskipun terdapat tema yang sama.

Jika dilihat dari latar informasi, informasi yang diberikan Viva.co.id secara detail mejelaskan kecemasan PNS yang akan dipindahtugaskan ke Ibu kota baru. Viva.co.id menampilkan narasumber utama yaitu para PNS yang memberi keterangan cemas jika dipindahkan karena fasilitias di Ibu kota baru yang mungkin tidak akan selengkap di Jakarta. Namun, terdapat pula narasumber sesama PNS yang memberi keterangan tidak masalah jika harus dipindahtugaskan. Pada pemberitaan Viva.co.id sendiri, terdapat kutipan narasumber dari pihak pemerintah yang memberi konfirmasi mengenai fasilitas yang akan diberikan pemerintah kepada masyarakat, termasuk PNS.

Dari latar belakang informasi yang diberikan kedua media online tersebut, Viva.co.id menghadirkan dua sudut pandang narasumber sehingga keduanya saling mengkonfirmasi dan memberikan kejelasan sedangkan Okezone.com hanya menghadirkan narasumber dari satu sudut pandang saja dan menyertakan dukungan kepada pemerintah dalam pemindahan Ibu kota negara, salah satunya adalah BKKBN.

Terdapat pula perbedaan pernyataan penulis atau wartawan dalam berita. Okezone.com menuliskan opini yang mendukung pemerintah bahwa ASN harus siap sedia ditugaskan di mana pun karena sudah diatur dalam Undang-Undang serta perjanjian kerja dengan pemerintah sedangkan opini yang ditulis oleh wartawan Viva.co.id adalah mulai dari jumlah PNS yang ada dan yang berencana akan dipindahtugaskan, serta berhubungan dengan para PNS yang khawatir terhadap fasilitas yang ada di Ibu kota baru yang tak selengkap di Jakarta, salah satunya adalah hiburan. Tiga opini lainnya yaitu menanggapi pemerintah yang mendukung PNS muda untuk siap dipindahkan serta janji pemerintah terhadap terpenuhinya fasilitas di Kalimantan Timur nanti.

Untuk struktur skrip, kedua media online tersebut sudah memenuhi unsur berita, yaitu $5 \mathrm{~W}+1 \mathrm{H}$ sehingga informasi yang disampaikan jelas sumbernya. Tidak hanya pada struktur skrip saja, pada struktur tematik pun kedua media online ini memiliki proposisi paragraf yang berkesinambungan sehingga penulisan alur antar paragraf jelas menjadi satu kesatuan informasi. Hal demikian didukung dengan kutipan narasumber yang memberikan informasi terkait pembahasan pada paragraf tersebut.

Penggunaan gambar oleh kedua media online tersebut sama-sama menggunakan gambar para PNS, berdasarkan keterangan yang diberikan di bawah gambar oleh penulis.

\section{Transportasi}

\section{Hasil Analisis Berita 3}

Hasil analisis pada berita ketiga yaitu perbedaan judul pada kedua media online tersebut. Meskipun kedua media sama-sama akan membahas transportasi, penggunaan judul pada media Viva.co.id terkesan menggiring opini 
pembacanya. Pemilihan judul Ibu Kota Siap Pindah, Sistem Transportasinya Apa Kabar? seolah-olah akan membuat pembaca membandingkan Jakarta dengan Ibu kota baru yang mungkin daerahnya sangat tertinggal sedangkan dari segi pemilihan judul, Okezone.com lebih to the point terhadap rencana pemerintah membangun transportasi di Ibu kota baru yang akan berbasis tenaga listrik.

Dari latar belakang informasi, Viva.co.id menjelaskan rencana pemerintah membangun dua model transportasi beserta dengan contohnya. Hal tersebut jelas. Namun, latar belakang informasi yang dituliskan penulis Okezone.com lebih terperinci, mulai dari anggaran dana hingga model transportasi apa yang akan dikembangkan pemerintah di Ibu kota negara yang baru. Hal tersebut mengingat Kalimantan Timur sendiri sudah memiliki transportasi seperti bandara sehingga hanya perlu membangun dan mengembangkan transportasi lain yang dibutuhkan nantinya.

Perbedaan paling jelas adalah dari segi narasumber. Penulis Viva.co.id sama sekali tidak menampilkan narasumber untuk mengkonfirmasi berita tersebut. Penulis hanya menggunakan dokumen dari VivaNews saja dan tidak melakukan konfirmasi ulang untuk informasi yang diberikan sedangkan Okezone.com menampilkan kutipan narasumber dari wakil presiden saat itu yaitu Jusuf Kalla. Hal tersebut sesuai dengan isi pemberitaan mengenai rencana pemerintah membangun dan mengembangkan transportasi di Ibu kota baru.

Untuk struktur skrip, kedua media online tersebut sudah memenuhi unsur berita, yaitu $5 \mathrm{~W}+1 \mathrm{H}$ sehingga informasi yang disampaikan jelas sumbernya. Tidak hanya pada struktur skrip saja, pada struktur tematik pun kedua media online ini memiliki proposisi paragraf yang berkesinambungan sehingga penulisan alur antar paragraf jelas menjadi satu kesatuan informasi. Hal demikian didukung dengan kutipan narasumber yang memberikan informasi terkait pembahasan pada paragraf tersebut.

\section{Pembahasan}

Penggunaan gambar oleh kedua media online tersebut sama-sama menggunakan gambar transportasi yang ada di Jakarta yaitu Kereta Api Indonesia dan MRT. Namun pemilihan gambar pada media Okezone.com lebih dianggap sinkron terhadap berita. Pada media Via.co.id, meskipun sedikit dibahas penulis, transportasi MRT bukanlah topik utama pembahasan berita.

Temuan-temuan yang dihasilkan melalui teknik analisis data dikaitkan dengan teori yang digunakan dalam penelitian ini untuk menjelaskan bagaimana cara wartawan mengkonstruksi sebuah berita agar menjadi berita yang dapat dinikmati khalayak sesuai dengan fakta atau peristiwa yang sebenar-benarnya terjadi. Jika dicermati secara teliti, seluruh isi artikel berita pada media online, antara lain media online Viva.co.id dan Okezone.com, menggunakan bahasa, baik verbal maupun non verbal (gambar, foto, dan kata-kata). Pemilihan judul, narasumber, kutipan narasumber, dan angle pada kedua media online tentunya akan berbeda. Untuk lebih mandalam lagi dalam melihat pembingkaian berita pada media online Okezone.com dan Viva.co.id, peneliti menggunakan analisis pembingkaian model Zhongdan Pan dan Gerald .M. Kosicki. Analisis pembingkaian model Zhongdan Pan dan Gerald .M. Kosicki membuat model yang berasumsi bahwa setiap berita mempunyai frame yang berfungsi sebagai pusat dari organisasi ide.

Pembingkaian ini merupakan suatu ide yang dihubungkan dengan point yang berbeda dalam teks berita seperti kutipan sumber, latar informasi, pemakain kata atau kalimat tertentu ke dalam teks berita secara keseluruhan. Pembingkaian berhubungan dengan makna. Bagaimana seseorang memaknai suatu peristiwa dapat dilihat dari perangkat tanda yang dimunculkan dalam teks. 
Penelitian ini bersifat deskriptif kualitatif, maka peneliti memberikan pemaknaan mendalam hanya pada struktur dan proses kognitif penulis atau wartawan dalam mengelola dan menyampaikan. Untuk melihat bagaimana wartawan mengolah dan menyampaikan peristiwa menjadi berita, peneliti melihat dari berita yang dimuat dua media online yang diteliti yaitu Okezone.com dan Viva.co.id. Pemaknaan pembingkaian berita ini dilakukan melalui analisis pembingkaian model Zhongdan Pan dan Gerald .M. Kosicki dengan menggunakan empat pembingkaian, yaitu sintaksis, skrip, tematik, dan retoris. Dengan model Zhongdan Pan dan Gerald. M. Kosicki ini, peneliti mendapatkan gambaran mengenai pembingkaian kedua media online yaitu Okezone.com dan Viva.co.id dari beberapa tema pemberitaan yang disampaikan.

Perbedaan pembingkaian berita ini terjadi karena adanya perbedaan ideologi yang diterapkan oleh kedua media online tersebut. Dari kepemilikan, media Okezone.com berada di bawah naungan Hary Tanoesudibjo dari Perindo yang menjadi partai pendukung Jokowi sehingga berita tampak mendukung (pro) kepada keputusan pemerintah (Jokowi) dalam memindahkan Ibu kota negara ke Kalimantan Timur sedangkan Viva.co.id merupakan milik Aburizal Bakrie dari partai Golkar yang banyak memiliki persoalan dengan Jokowi di masa orde baru.

Jika dikaitkan dengan penelitian terdahulu, Losianti (2015) terlebih dahulu meneliti pembingkaian yang dilakukan oleh media online Viva.co.id dengan kasus Mundurnya Surya Paloh Dari PartaI Golkar. Dari hasil penelitian, menurut Losianti (2015), media online Viva.co.id dinilai masih menunjukkan usaha media untuk melakukan pendekatan pada objektifitas pemberitaan, hal tersebut dipengaruhi oleh kepemilikan media itu sendiri. Pendekatan pada objektifitas pemberitaan masih diterapkan oleh kedua media online ini. Hal tersebut terjadi karena setiap media memiliki ideologinya masing-masing sehingga mereka akan membingkai keduanya sesuai ideologi yang diterapkan.

Dari penelitian terdahulu yang sudah dikumpulkan oleh penulis, dapat disimpulkan bahwa setiap media memiliki caranya masing-masing dalam membingkai berita. Mulai dari pemilihan judul, bahasa, gambar, narasumber dan pemilihan katanya. Sehingga meskipun beberapa media membahas tema yang sama, tentu akan dikemas dengan cara yang berbeda dan tidak jarang akan menggiring opini jika media tersebut masih berpegang kepada kepemilikan media dan informasi yang disampaikan berkaitan dengan kepemilikan media itu sendiri.

Pada penelitian ini pun terlihat bagaimana media online Okezone.com maupun Viva.co.id membingkai suatu peristiwa pemindahan Ibu kota Indonesia. Dalam penelitian ini pun ditemukan keterkaitan kepemilikan media dengan berita yang disampaikan. Sebagaimana telah disampaikan, kepemilikan media Okezone.com merupakan milik Hary Tanoesoedibjo yang berasal dari Perindo. Perindo sendiri merupakan salah satu partai pendukung Jokowi pada pilpres lalu. Pada penyampaian berita, Okezone.com hanya menggunakan narasumber dari pihak yang mendukung pemindahan Ibu kota Indonesia ini dan tidak ada sanggahan atau kutipan dari narasumber dari sudut pandang lain.

Viva.co.id sendiri memberitakan pemindahan Ibu kota Indonesia ini dengan cukup netral. Viva.co.id selalu menggunakan narasumber dari dua sudut pandang berbeda meskipun penggunaan judulnya terkesan menggiring opini publik.

131 | Alifia Pradyanti et al.: Framing News about Indonesian Capital City Translocation... 


\section{PENUTUP}

\section{Kesimpulan}

Media dengan mudah mengemas berita sedemikian menarik untuk disampaikan kepada masyarakat, entah untuk benar-benar memberikan informasi kepada masyarakat atau untuk mempertahankan ideologi media itu sendiri. Pada dasarnya, satu topik besar dapat diberitakan berbeda oleh beberapa media. Seperti itulah media mengemas berita. Tidak terkecuali yang dilakukan pada media yang dipilih pada penelitian ini yaitu media online Okezone.com dan Viva.co.id.

Seperti diketahui, banyak orang menganggap kepemilikan kedua media online ini berbanding terbalik. Oleh karena itu, penelitian ini mengungkapkan bagaiman kedua media membingkai berita khususnya terkait pemindahan Ibu kota Indonesia. Pada penggunaan teori framing, Zhongdan Pan dan M. Kosicki memiliki unsur yang paling lengkap, mulai dari struktur hingga isi diteliti lebih jelas dan detail.

Framing pemberitaan oleh media Okezone.com dan Viva.co.id pada struktur sintaksis mengalami perbedaan pada pemilihan narasumber. Viva.co.id menggunakan lebih dari satu narasumber dalam pemberitaan sedangkan Okezone.com lebih menggunakan satu pihak narasumber. Namun, pada satu berita Viva.co.id tidak ditampilkan narasumber sama sekali. Dari segi gambar pun pemilihannya tidak jauh berbeda antara kedua media. Perbedaan paling menonjol adalah pada judul pemberitaan, Viva.co.id terkesan kontra terhadap pemindahan Ibu kota Indonesia sedangkan Okezone.com terkesan pro terhadap pemindahan Ibu kota Indonesia.

Dari struktur skrip, kedua media sama-sama memiliki kelengkapan unsur berita berupa adanya $5 \mathrm{~W}+1 \mathrm{H}$. Viva.co.id kurang memperhatikan kelengkapan berita dari segi pemilihan narasumber. Tidak ada narasumber yang dimintai keterangan pada berita ketiga sedangkan Okezone.com kurang memperbanyak narasumber dari sudut pandang yang berbeda.

Berita di Viva.co.id maupun Okezone.com telah dikemas dan dibingkai. Pada dasarnya, masing-masing media memiliki ideologi berbeda terhadap berita yang mereka tulis walaupun berita-berita dalam topik atau tema sama.

Penggunaan gambar, baik pada Okezone.com maupun Viva.co.id, tidak jauh berbeda. Pemilihan gambar keduanya selaras dengan informasi apa yang akan disampaikan penulis kepada pembaca.

Pada penelitian ini pun ditemukan keterkaitan kepemilikan media dengan berita yang disampaikan. Sebagaimana telah disampaikan, media Okezone.com merupakan milik Hary Tanoesoedibjo yang berasal dari Perindo. Perindo sendiri merupakan salah satu partai pendukung Jokowi pada Pilpres lalu. Pada penyampaian berita, Okezone.com hanya menggunakan narasumber dari pihak yang mendukung pemindahan Ibu kota Indonesia dan tidak ada sanggahan atau kutipan dari narasumber dari sudut pandang lain.

Viva.co.id memberitakan pemindahan Ibu kota Indonesia ini dengan cukup netral. Viva.co.id selalu menggunakan narasumber dari dua sudut pandang berbeda meskipun penggunaan judulnya terkesan menggiring opini publik.

\section{Saran}

Hasil penelitian terkait framing mengenai Berita Pemindahan Ibu Kota Indonesia pada media online Okezone.com dan Viva.co.id dengan menggunakan teori framing model Zhongdan Pan dan Gerald M. Kosicki sudah cukup memberikan gambaran secara jelas dan lengkap melalui empat struktur, yaitu struktur sintaksis, 
skrip, tematik, dan retorik tentang bagaimana subjektivitas dan objektivitas berita yang diangkat dan ditonjolkan.

Namun, dalam penelitian ini belum ditekankan sejauh mana ideologi media dalam membingkai suatu berita untuk disampaikan kepada pembaca. Dalam pemilihan narasumber pun sebaiknya Okezone.com dapat menampilkan lebih dari satu agar menjadi berita yang lebih lengkap dan memenuhi kriteria, yaitu cover both sides. Selain itu, framing pun bisa dilakukan lebih dari dua media agar dapat terlihat dengan jelas bagaimana media membingkai suatu peristiwa dengan lebih terperinci dan dapat pula terlihat media mana yang lebih pro dan lebih kontra terhadap peristiwa yang diteliti.

Dalam penelitian ini, peneliti juga menyarankan agar masyarakat tidak langsung mengambil keputusan terhadap apa yang diberitakan setiap media. Masyarakat harus mampu berpikir cermat terhadap segala informasi dengan banyak membaca tidak hanya dari satu media saja, harus dari berbagai sumber agar jelas dan akurat karena media sangat mudah mempengaruhi khalayak dan khalayak yang tidak melakukan pengecekan dari berbagai sumber akan mudah percaya dan bisa dengan mudah menyebarkannya.

\section{DAFTAR PUSTAKA}

Desiana. (2016). Analisis Framing Berita Serangan Isis di Paris Pada Surat Kabar Harian Waspada.SIB dan Analisa, 1(1), 138-148.

Fakhri, F. (2019). Pemindahan Ibu Kota Negara Disambut Baik Warga Kalimantan. Diakses pada 20 September 2019 dari https://nasional.okezone.com/read/2019/08/17/337/2093075/pemindahan-ibu-kotanegara-disambut-baik-warga-kalimantan

Giri, H. (2019). Ibu Kota Baru Akan Miliki Kereta Berbasis Listrik. Diakses Pada 20 September 2019 dari https://economy.okezone.com/read/2019/09/13/320/2104449/ibu-kota-baru-akan-miliki-kereta-berbasis$\underline{\text { listrik }}$

Losiyanti, M. (2015). Analisis Framing Berita Mundurnya Surya Paloh Dari Partai Golkar di VIVA.co.id. Jurnal Ilmu Komunikasi, 3(1), 1-16.

No Name. (2019). Kecemasan Warga Dayak Paser Saat Ibu Kota Pindah ke Kalimantan Timur. Diakses Pada 20 September 2019 dari https://www.viva.co.id/berita/nasional/1178347-kecemasan-warga-dayak-paser$\underline{\text { saat-ibu-kota-pindah-ke-kalimantan-timur }}$

No Name. (2019). PNS Cemas Pindah ke Ibu Kota Baru, Khawatir Tak Selengkap Jakarta. Diakses pada 20 September 2019 dari https://www.viva.co.id/berita/nasional/1176913-pns-cemas-pindah-ke-ibu-kota-barukhawatir-tak-selengkap-jakarta

Nuhadi, Z.F.. (2015). Teori Komunikasi: Teori Komunikasi Dalam Perspektif Penelitian Kualitatif. Bogor: Ghalia Indonesia.

Nursyabila, M. (2019). BKN Susun Strategi Pindahkan PNS ke Ibu Kota Baru. Diakses pada 20 September 2019 dari

https://www.google.com/search?q=BKN+Susun+Strategi+Pindahkan+PNS+ke+Ibu+Kota+Baru\&rlz=1C1E 
$\underline{\text { JFA_enID777ID779\&oq }=\text { BKN+Susun+Strategi+Pindahkan }+ \text { PNS+ke+Ibu+Kota }+ \text { Baru\&aqs }=\text { chrome..69i5 }}$ 7j69i6012.899j0j1\&sourceid $=$ chrome\&ie $=$ UTF-8

Sugiyono. (2017). Metode Penelitian Kuantitatif, Kualitatif dan R\&D. Bandung: Alfabeta, CV.

Wendratama, E. (2017). Jurnalisme Online Panduan Membuat Konten Online yang Berkualitas dan Menarik. Yogyakarta: PT. Bentang pustaka.

Tim Viva. (2019). Ibu Kota Siap Pindah, Sistem Transportasinya Apa Kabar?. Diakses pada 20 September 2019 dari https://www.viva.co.id/berita/nasional/1176545-ibu-kota-siap-pindah-sistem-transportasi-apa-kabar 